YURI N. KUZMIN

UDC: 94(381)“652“"

Moscow City University

Samara branch

yurimac@yandex.ru

\title{
KING DEMETRIUS II OF MACEDON: IN THE SHADOW OF FATHER AND SON
}

\author{
For Vera Bitrakova Grozdanova
}

\begin{abstract}
The article is an attempt to summarize all the available information from sources about Demetrius II (239-229 B.C.), the most obscure king from the Antigonid dynasty, and the history of the Macedonian state during his reign. Among the others the following matters are considered: Demetrius' marriages when he was initially the heir to the throne and then the king; the possibility of his co-ruling with the father, Antigonus Gonatas; the calculation of Demetrius' regnal years; his internal, foreign and military policies.
\end{abstract}

\section{Introduction}

Back in his day, already J. G. Droysen raised objections against the view of Demetrius II (239-229 B.C.) as the least significant ruler of the Antigonid dynasty (306-168 B.C.). ${ }^{1}$ Such characteristics of Demetrius and his reign as the period of the decline of the Macedonian kingdom date back to the works of B. G. Niebuhr. ${ }^{2}$ Nevertheless, even now in the works of historians of classical antiquity the view of Demetrius II as the most obscure and inactive Antigonid king dominates; sometimes it is justified by the poor condition of the sources. ${ }^{3}$

The main sources for the life and the reign of Demetrius II are the works of Polybius, Plutarch (primarily his life of Aratus of Sicyon) and Trogus (in the epitome by Justin). Scattered but important information is to be obtained from Livy, Polyaenus, Josephus, Strabo, Eusebius, the so-called "Prologues" of the Historiae Philippicae of Trogus, Stephanus of Byzantium, as well as from several inscriptions (from Macedonia and abroad).

${ }^{1}$ Droysen 1955, 319 ("Demetrios, den neuere Historiker den unbedeutendsten Fürsten aus der Dynastie der Antigoniden nennen...”). Cf. Vasil'evskiy 1869, 179.

${ }^{2}$ Niebuhr 1828, 231; Niebuhr 1852, 307.

${ }^{3}$ E.g. Walbank 1984, 453; Errington 1990, 175. 
It is illustrative that of all the Antigonid kings it is only Demetrius II who has still not yet earned a monograph. ${ }^{4}$ Writers in the two recent Macedonian Companions give only slight attention to Demetrius II and to Macedonian history under his reign. 5

Also Demetrius II is largely overshadowed by his famous father and son: Antigonus II Gonatas (283-239 B.C.) and Philip V (221-179 B.C.). During the reign of Gonatas, who thanks to the efforts of W.W. Tarn has gained the reputation almost of a "philosopher-king", 6 the Antigonid dynasty finally became established in Macedonia as one of the great powers in the Hellenistic world. Under Philip V, the kingdom of the Antigonids reached the apogee of its power, but, having encountered a new force - Rome - lost the fight against it and lost its status as a great power. ${ }^{7}$

I shall now attempt to present the life and the politics of Demetrius II, as far as the sources permit. A book on the history of Macedonia during his reign still waits to be written.

\section{The Crown-Prince}

\subsection{Childhood and Education}

It seems difficult to determine even the year of birth of Demetrius. His parents were Antigonus Gonatas and Phila, a princess from the Seleucid dynasty, the daughter of Seleucus I, step-sister of Antiochus I, and niece of Gonatas himself. According to the biography of the poet Aratus of Soli, who had attended the wedding of Antigonus and Phila, ${ }^{8}$ their marriage was celebrated after 277-276 B.C., when Gonatas took power in Macedonia. ${ }^{9}$

In order to date the birth of Demetrius we might employ the information of Justin, who in his mention of the son of Antigonus Gonatas during the events that took place some time near the end of the Chremonidean War (c. 268-262 B.C.) speaks of him as of an adolescent (puer admodum). ${ }^{10}$ This expression and the context of Justin's narrative

4 On Demetrius II and the history of Macedonia during his reign, see Kaerst 1901a, 2792-2793; Volkmann 1964, 1465; Ehrhardt 1975, I, 198-222 (and passim); Hammond - Walbank 1988, 317-336; Hammond 1989, 315-318; Errington 1990, 173-175; Badian 1997, 429.

${ }^{5}$ Adams 2010, 221-223; Lane Fox 2011, 517-519. Cf. King 2018, 241-242.

${ }^{6}$ E.g. Tarn 1913, 256. Antigonus Gonatas undoubtedly showed an interest in philosophy, but yet he could hardly have been the "philosopher-king" as many classicists after Tarn want to see him (e.g. Green 1990, 61-62, 141-143, 199).

7 The opinion of Treves 1932, 199, that already Demetrius II had been impressed by the Romans' success in the First Punic War and was preparing for a confrontation with Rome, is unjustified (cf. Ehrhardt 1975, I, 5).

${ }^{8}$ Vita Arati IV, pp. 19-20 Martin.

${ }^{9}$ Cf. Tarn 1913, 173-174.

${ }^{10}$ Just. 26.2.11. 
(see below) confirm the fact that Demetrius was quite capable at the time but in all probability had not yet reached the age of sixteen. Thus the son of Antigonus and Phila Demetrius, named in honour of his famous grandfather Demetrius I Poliorcetes, must have been born in the second half of the 270's B.C. It could have been $c$. $275-274$ B.C. ${ }^{11}$

Probably Demetrius was born some time before the last invasion of Macedonia by Pyrrhus in 274 B.C. Pyrrhus had defeated Gonatas and forced him to flee to Thessalonice. ${ }^{12}$ It is likely that it was here that the king's family had been. However, soon Pyrrhus left Macedonia, which enabled Antigonus to regain his control of the country. The final clash between Gonatas and Pyrrhus, which resulted in the death of the Epirote king, took place in the Peloponnese in the battle on the streets of Argos in the autumn of 272 B.C.

Antigonus Gonatas had an elder son, Demetrius's step-brother Halcyoneus, whose mother had been Demo, an Athenian hetaira. ${ }^{13}$ There have been suggestions that originally it could have been Halcyoneus who was regarded by Antigonus as the crown-prince despite the status of his mother. ${ }^{14}$ But the sources have no direct indications of the position of Halcyoneus in the court of Antigonus. In 272 B.C. Halcyoneus together with his father fought in the campaign against Pyrrhus in the Peloponnese. It was Halcyoneus who threw the head of Pyrrhus at the feet of Antigonus. ${ }^{15}$

It is beyond doubt that Halcyoneus's position in the court of Antigonus was of importance not only during the period when he was the only son, but remained so after Phila gave birth to Demetrius II. However, the eldest son of Gonatas did not outlive his father. Halcyoneus fell in an uncertain battle, ${ }^{16}$ perhaps during the Chremonidean War, and the question of his right to the throne remains open.

It is difficult to say anything definite about the childhood and education of Demetrius. One thing raises no doubt: Antigonus Gonatas was an educated man himself, and he will have striven to give a proper education to his heir. Many representatives of the Greek intellectual elite were in the court of Gonatas, among them the Stoic philosopher Perseus, a disciple of Zeno of Cytium, who lived in Macedonia for a long time, until the 240's B.C. It follows from Diogenes Laertius that Perseus was the tutor of Halcyoneus. ${ }^{17}$ It is quite probable that later Perseus was the tutor of Demetrius as well.

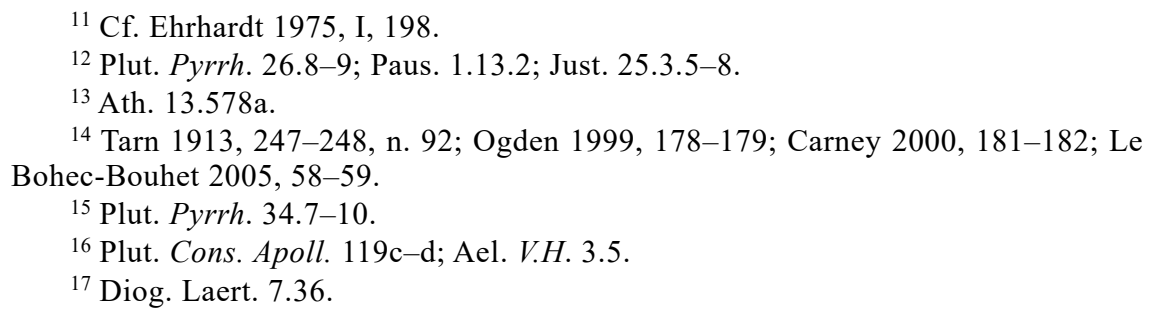


It is possible also that it was Demetrius to whom a famous saying of Antigonus Gonatas was addressed: the king spoke to his "son", who had been in some way impertinent to his subjects, and instructi-

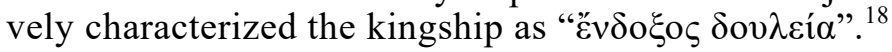

Demetrius was probably the only child of Gonatas and Phila. ${ }^{19}$ The physique of Demetrius II is unknown, since no images of him have survived (or at least have been identified).

\subsection{Demetrius and the Chremonidean War}

The first mention of Demetrius in the sources refers to the time of the Chremonidean War (c. 268-262 B.C.), when Macedonia was opposing a coalition of several Greek states (Athens, Sparta and others) and Ptolemy II. ${ }^{20}$ At the time when Antigonus Gonatas was heading the military operations in Attica and Isthmus, the king of Epirus Alexander II, son of Pyrrhus, invaded Macedonia. ${ }^{21}$ Antigonus had to hurry to Macedonia, but, according to Justin, his warriors deserted to the king of Epirus. After that Gonatas disappears from the narrative of Justin, and the war against Alexander was continued by the son of the Macedonian king, Demetrius. ${ }^{22}$ It is likely enough that the misfortune of Antigonus and the success of Alexander II were exaggerated by Justin, who had an inclination towards dramatisation, ${ }^{23}$ and Gonatas (if he ever came back to Macedonia and really was defeated) thought it possible to resume military operations in Greece while entrusting the continued war against the Epirotes to his son.

With his father away, Demetrius defeated Alexander and expelled him from Macedonia. ${ }^{24}$ According to Eusebius, Demetrius' victory over Alexander's took place at "Derdia", ${ }^{25}$ most likely somewhere in Western Macedonia, where in the region of Elimiotis in the fifth and fourth centuries B.C. there were several rulers with the name of Derdas. ${ }^{26}$ Then, as Justin says, Demetrius headed the Macedonian army in

${ }^{18}$ Ael. V.H. 2.20. Cf. Lane Fox 2011, 498. Meanwhile, it is not known precisely which of the sons of Gonatas is mentioned by Aelian. Some scholars tend to think it was not Demetrius but Halcyoneus (e.g. Tarn 1913, 256, n. 122).

${ }^{19}$ On Delos a dedication was made by the Therapeutists of Sarapis and Isis probably "on behalf of king Antigonus, and queen Phila, and Demetrius" (IG XI.4 1215:

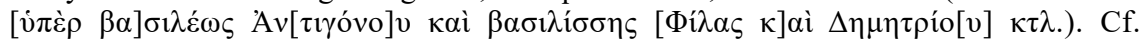
Kotsidu 2000, 198-199 (124[e]).

${ }^{20}$ See Mikroyannakis 1999, 753-761.

${ }^{21}$ Just. 26.2.9-11.

22 Just. 26.2.11.

${ }^{23}$ Some historians deny the full accuracy of the information about the desertion of Antigonus' warriors to Alexander (e.g. Heinen 1972, 176; Hammond - Walbank 1988, 285, nn. 4, 6).

${ }^{24}$ Just. 26.2.11.

${ }^{25}$ Euseb. Chron. I.243 Schoene.

${ }^{26}$ E.g. Thuc. 1.57.3; Xen. Hell. 5.2.8. Cf. Tarn 1913, 304; Heinen 1972, 176. 
its invasion of Epirus, thus inducing Alexander to flee to neighbouring Acarnania (some time later Alexander returned to Epirus). ${ }^{27}$ The victory of Demetrius secured the safety of Macedonia and enabled Antigonus Gonatas to focus on crushing the anti-Macedonian coalition in Greece.

Of course, Demetrius's age (he must have been $c .12$ years old at the time) raises doubts as to whether he himself commanded the army. There has been speculation that Justin could have mistaken for the future Demetrius II Demetrius the Fair, ${ }^{28}$ half-brother of Gonatas, later ruler of Cyrene. ${ }^{29}$ However, Justin's information is confirmed by Eusebius, who also makes a note of the victory of "Demetrius, the son of Antigonus" over the king of Epirus (however, Eusebius mistakes Alexander for his father Pyrrhus) ${ }^{30}$ It must be mentioned that this case is not one of a kind; according to Livy, in 199 B.C. during the Second Macedonian War the 13-year-old Perseus, son of Philip V, led a part of the army, assisted by his father's friends. ${ }^{31}$ Most likely, Demetrius was also surrounded by experienced generals, but the glory of the victory went to the king's son. Such was the prominent military and political debut of Demetrius II.

\subsection{The First Marriage of Demetrius}

In the second half of the 250's B.C. the first of the several marriages of the son of Antigonus Gonatas took place. Demetrius married Stratonice, the daughter of the Seleucid king Antiochus II (261-246 B.C.). ${ }^{32}$

It could be that the marriage of Demetrius and Stratonice was related in time with the wedding of her father and Berenice, daughter of Ptolemy II, which was effected after the end of the Second Syrian War (c. 253 B.C.). The end of this war, in which the great and some

${ }^{27}$ Just. 26.2.11-3.1.

${ }^{28}$ A case is known when Eusebius (or it could have been his source, Porphyry) clearly mistakes Demetrius II and Demetrius the Fair (Euseb. Chron. I.237-238 Schoene).

${ }^{29}$ E.g. Droysen 1955, 154, n. 149; Kaerst 1901b, 2793.

${ }^{30}$ Euseb. Chron. I.243 Schoene.

${ }^{31}$ Livy 31.28.5; 31.33.3.

32 For the details see Gabelko - Kuzmin 2019, 202-225. In this work it is shown that Stratonice, who became the wife of Demetrius, was the daughter and not the sister of Antiochus II, as the sources refer to her (Euseb. Chron. I.249 Schoene; Agatharchid. ap. Jos. Ap. 1.206; Just. 28.1.1-2). In brief: on ascending to the throne in 261 B.C. Antiochus II was 26 years old according to Eusebius (Chron. I.251 Schoene), and probably about the same time he gave his "daughter" (also called Stratonice) in marriage to the future Ariarathes III of Cappadocia (Diod. 31.19.6; Euseb. Chron. I.251 Schoene). If that was the case, Antiochus' daughter was still a child. Obviously in the sources two Stratonices are confused: it was Antiochus' sister who was married to the Cappadocian prince c. 260-258 B.C., while later the daughter of Antiochus was married to the future Demetrius II of Macedon. 
minor Hellenistic states had found themselves involved, might have been marked by dynastic marriages afterwards: Antiochus II and Berenice as well as Demetrius and Stratonice.

Stratonice had not produced a heir to Demetrius, which probably undermined her status in the Antigonid court. Nevertheless, she remained in Macedonia until the mid 240's or, possibly, even the early 230's B.C. ${ }^{33}$

\subsection{Demetrius as a co-ruler with Antigonus Gonatas}

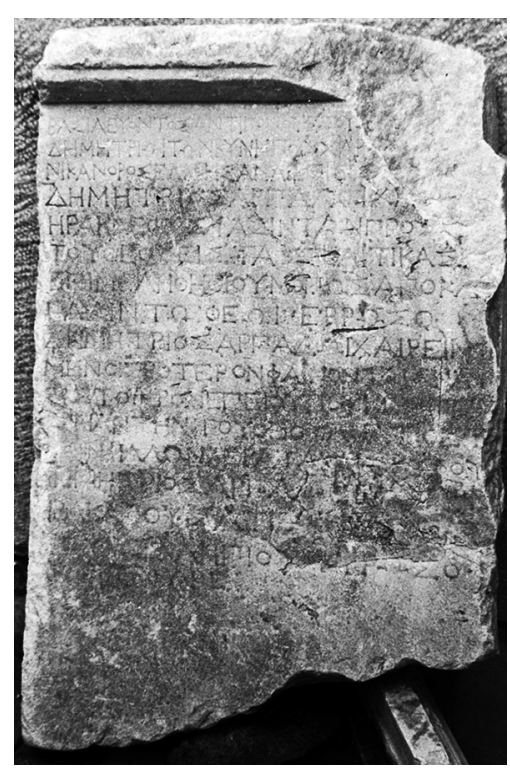

Fig. 1: Letters of Demetrius to Harpalus (The Archaeological Museum of Veria, photograph by Yu. Kuzmin, 2002)

Year 36 of the reign of Antigonus Gonatas (248 B.C.) is the date of an inscription from Beroea (Fig. 1), one of the most important cities of Macedonia, with three letters from Demetrius to Harpalus, ${ }^{34}$ who in all probability had been an epistates, a magistrate responsible for liaising with the king and fulfilment of the royal orders. ${ }^{35}$ In those letters Demetrius, beyond doubt the son of Gonatas, on his own authority gives orders on the income of temples and the dedication of vessels to temples by freedmen, and grants ateleia (exemption from taxes) to the priests of Heracles Cynagidas ("the Hunter"). This attests Demetrius' fairly broad authority during his father's life.

Another inscription from Beroea, an act of manumission (Fig. 2), allows us to suppose that Demetrius was not only the de facto co-ruler with Antigonus Gonatas, but a bearer of the royal title as well. The manumission is dated to year 27 of the reign of a certain Demetrius. ${ }^{36}$ However, both Macedonian

${ }^{33}$ Apama, the supposed sister of Philip V and wife of Prusias I of Bithynia, who is usually considered to be the daughter of Demetrius II and Stratonice (e.g. Carney $2000,185,187)$, could perhaps have been born to Phthia, another wife of Demetrius (see below). At the same time, the reason why the daughter of Demetrius II had an Eastern/Seleucid name remains uncertain, since her mother was not of Seleucid origin.

${ }^{34}$ EKM I 3.

${ }^{35}$ Harpalus belonged to a noble family which had an important role both in Beroea and in the court of the Antigonids in the third and second centuries B.C. (see Kuzmin 2013a, 123-132).

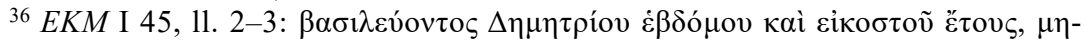

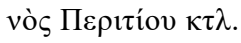


kings of this name, Demetrius I Poliorcetes and his grandson Demetrius II, ruled for shorter periods. Even if one counts the years of Demetrius I from his acceptance of the title basileus in 306 B.C. after the victory at Salamis of Cyprus to his death in 283 or 282 B.C., the period will be around $23-24$ years. ${ }^{37}$ Demetrius II, the son of Antigonus Gonatas, ruled only for 10 years (239-229 B.C.). ${ }^{38}$

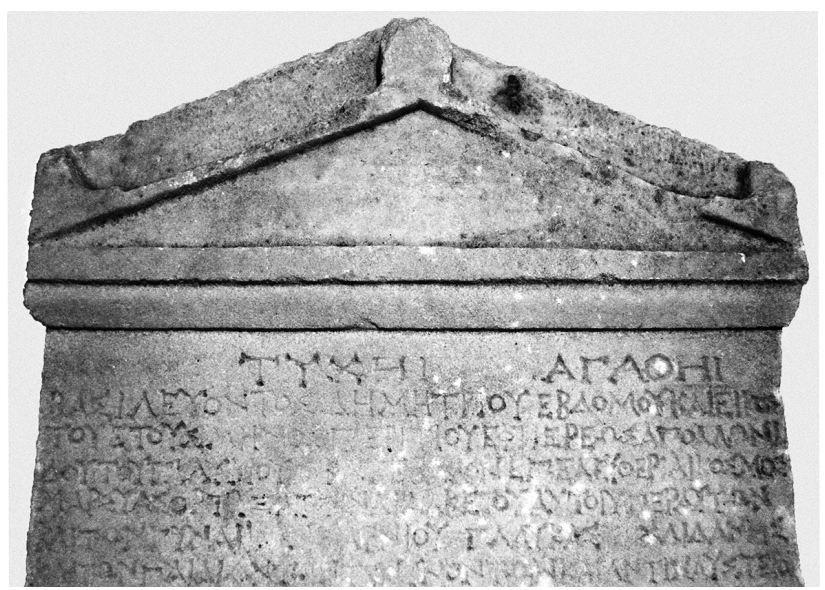

Fig. 2: The upper part of the manumission dated by the "year 27 of the reign of Demetrius" (The Archaeological Museum of Veria, photograph by Yu. Kuzmin, 2016)

Many classicists, starting with M. Andronikos, the first editor of the manumission, have tended to explain its dating by assuming a co-regency of Antigonus Gonatas and his son (the unambiguous evidence for that is another inscription from Beroea, the above-mentioned "Letters of Demetrius to Harpalus"). ${ }^{39}$ The association of heirs in the government,

37 The theory of Errington 1977, 115-122, who considered the manumission from Beroea to have been dated posthumously with the regnal years of Demetrius I Poliorcetes counted from 306 B.C. and, thus, to belong to the time around 280-279 B.C. (after Poliorcetes had not only lost Macedonia but had died as well) cannot be accepted. Grzybek 1993, 521-527, had noticed that from 317/6 B.C. some Babylonian cuneiform documents were dated by the name of Antigonus Monophthalmus (however, without the title of "king"). Grzybek proposed that even after Monophthalmus had accepted the title basileus in 306 B.C. the period of his "reign" was calculated not from that moment, but from 317/6 B.C. In due course, this system (a de facto dynastic era) was used by Monophthalmus' son Demetrius Poliorcetes during his reign in Macedonia in 294-288 B.C. Thus, according to Grzybek, the manumission from Beroea should be dated 291 or 290 B.C., but he is obviously wrong in the case of this inscription. See critics of Errington's and Grzybek's hypothesis in Hatzopoulos 1990, 144-147; Kuzmin 2013b, 108-123; Kuzmin 2015, 74-79.

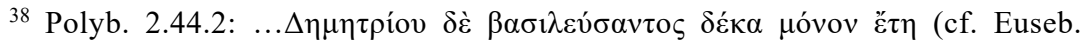

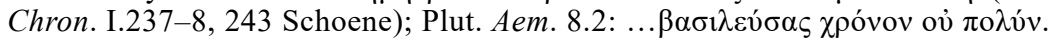

${ }^{39}$ E.g. Andronikos 1950, 18-21; Manni 1956, 266, n. 2; Cabanes 1976, 58-65; Will 1979, 343-344, 347-348; Mikroyannakis 1986, 393-399; Tataki 1988, 64 and n. 173; Hammond - Walbank 1988, 317-318; Hatzopoulos 1990, 144-147; Lane Fox 2011, 498, 512, 518; Kuzmin 2013b, 108-123. 
and sometimes the granting of royal titles to them, was a common practice in the Hellenistic monarchies. It was with the co-reign of Antigonus $\mathrm{I}$ and Demetrius I that the history of the Antigonid dynasty started in 306 B.C. ${ }^{40}$

It is important that Polyaenus mentions Demetrius II as a basileus in Gonatas' lifetime, c. 245 B.C. in the connection of the wedding of Demetrius and Nicaea (see below). ${ }^{41}$

It is probable that upon starting his individual rule in 239 B.C. Demetrius II began to count his "reign" from the beginning of his participation in the government (i.e. not later than 256 B.C.) ${ }^{42}$ although during the reign of Gonatas the name of his son was not included in the dating formulas. ${ }^{43}$

However, there are two documents showing that Demetrius II counted his reign from the time of Gonatas' death in 239. The treaty with Gortyn is dated to year 3 of Demetrius II. ${ }^{44}$ According to the "traditional" 10-year chronology of the reign of Demetrius II, the treaty with Gortyn must be dated to 237 B.C., which corresponds well with the political situation of this time, when the so-called "Demetrian War" (c. 238-229 B.C.) had started, and the king needed allies and mercenaries to fight against the Aetolian-Achaean alliance. Quite recently there has been published a letter of Philoxenus, a citizen of Pythium in Perrhaebia, to Demetrius II, and the decision of the king in his year 6 (counted obviously from 239 B.C.) is mentioned in this document (but year 6 is not the actual date of the letter). ${ }^{45}$

Thus the dating of the manumission from Beroea remains an enigma, but it seems that assuming a co-regency of Demetrius II and his father explains it best. ${ }^{46}$ One can assume the co-existence of two dating systems of Demetrius II's reign or the introduction for some unknown reason of a retrospective dating after the sixth year of his reign evidenced in the inscription from Pythium. ${ }^{47}$

${ }^{40}$ Diod. 20.53.2-3; Plut. Demetr. 17.5-18.1; id. Aem. 8.1; App. Syr. 54; Just. 15.2.10.

${ }^{41}$ Polyaen. 4.6.1.

42 Demetrius's military leadership in the war against Alexander of Epirus (see above) could be the starting point for the "long chronology" of his reign (cf. Andronikos 1950, 20-21; Mikroyannakis 1999, 758).

${ }^{43}$ EKM I 3, 1.1 (Beroea, 248 B.C.); IG XII.4.1 220.ii, 1. 19 (Amphipolis, 243 or 242 B.C.).

${ }^{44}$ IC IV $167=$ SVA III 498, 11. 1-2.

45 Tziafalias - Helly 2010, 72-73 = Bull. ép. $2011399=$ SEG LX 604.

${ }^{46}$ A natural analogy to this is the dating system of Ptolemy II Philadelphus, who first counted his reign from 282 B.C., i.e. after the death of Ptolemy I Soter, but eventually switched to counting from 285 B.C., when he was declared co-regent with his father (see Hazzard 1987, 140-158). Notably, in Soter's lifetime the name of the future Philadelphus was not included in the dating formulas of documents (PEleph 24); cf. Buraselis 2005, 94.

${ }^{47}$ It appears that an additional argument in favour of the opinion that Demetrius II, not Poliorcetes, is mentioned in the manumission from Beroea, is the fact that the 


\subsection{Gonatas and Corinth, Demetrius and Nicaea}

It was shown above that the "Letters of Demetrius to Harpalus" demonstrate that in 248 B.C. Demetrius, probably in the absence of his father, ruled the kingdom on his own. Gonatas could have been absent from Macedonia in connection with a revolt in Corinth of his nephew Alexander, son of Craterus, ${ }^{48}$ who declared himself an independent ruler c. 250-249 B.C. In the "Prologues" to the Historiae Philippicae of Trogus as well as in Athenian inscriptions there is mentioned a war that Antigonus and his allies (Argos and Athens) waged against Alexander. ${ }^{49}$

The restoration of control over Corinth became possible for Gonatas only by way of a "dynastic marriage" after the death of Alexander (c. 245 B.C.). The Macedonian king proposed to Alexander's widow Nicaea, who, after her husband's death controlled his domain, that she should marry Demetrius. Nicaea agreed. Colourful descriptions of the wedding ceremonies in Corinth are present in the works of Plutarch and Polyaenus. ${ }^{50}$ They both note that Nicaea was older than Demetrius, who at the time must have been c. 28-29 years old.

In the very midst of the festivities, when the famous harp-player Amoebeus was about to perform in the theatre, Gonatas took over Acrocorinth. Nothing is known about the fate of the "marriage" of Demetrius and Nicaea. There were speculations that the marriage was broken immediately after the king's garrison occupied Acrocorinth, or that the marriage never took place at all. ${ }^{51}$ One way or another, Nicaea is never again mentioned in the sources in connection with Demetrius. It is probable, however, that it was after Nicaea had lost Corinth and had been "married" to Demetrius that her romantic relationship with the poet Euphorion ensued. ${ }^{52}$

It is not known exactly when Stratonice, the first wife of Demetrius, left Macedonia: before the "wedding" of Demetrius and Nicaea or later, before his marriage to Phthia (see below).

The recovery of Corinth was to be one of the last successes of Antigonus Gonatas. The remaining several years of his life were marked by the weakening of the position of the Antigonid state. In the second half of the 240's B.C. the Ptolemies established control over some territories in the area of the Hellespont and southern Thrace in the vicinity of the Macedonian frontiers, and in 243 B.C. the Achaeans led

practice of publishing manumissions (at Delphi, Boeotia, Thessaly, Epirus, and other places) became widespread only in the second century B.C. (cf. on the chronology Zelnick-Abramovitz 2005, 64).

${ }^{48}$ Cf. Chambers 1954, 390-391.

${ }^{49}$ Trog. Prol. 26; IG $\mathrm{II}^{3} 1019 ; \mathrm{II}^{2}$ 1225. See for the details Hammond - Walbank 1988, 301-305; Dixon 2014, 91-98.

${ }^{50}$ Plut. Arat. 17.2-7; Polyaen. 4.6.1.

${ }^{51}$ Cf. Tarn 1913, 373; Porter 1937, 61; Ehrhardt 1975, I, 200; Gabbert 1997, 57.

${ }^{52}$ Suda s.v. Eủpopíwv; cf. Plut. De Tranq. Anim. 472d. 
by Aratus of Sicyon captured Corinth. The legacy that Antigonus Gonatas left to his son was not very simple.

\section{The King}

\subsection{The State and Court}

In 239 B.C., after the death of Antigonus Gonatas, Demetrius then aged c. 35, succeeded to the Macedonian throne. It is likely that it was for this reason that the "Demetreia" festival was founded on Delos. ${ }^{53}$

Demetrius ruled a vast kingdom: apart from Macedonia per se it included Thessaly, Euboea (or at least a part of island) and some other territories. ${ }^{54}$ Athens and several states in the Peloponnese were within the Antigonid sphere of influence.

Demetrius's accession happened at a time of radical change in the political situation in Greece, where the recent rivals, the Achaean and Aetolian Leagues, agreed to unite their effort to fight the weakening kingdom of the Antigonids and to expel the Macedonians from Greece. ${ }^{55}$ In that situation Demetrius had to concentrate on the defence of the sphere of influence of Macedonia and its allies in Greece. Besides, Demetrius was supporting several tyrant regimes in the Peloponnese. According to Polybius, Demetrius II was for the Greek tyrants

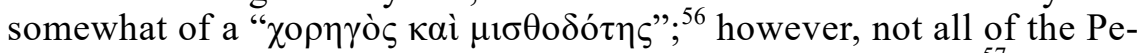
loponnesian tyrants were protegés of Demetrius or his father. ${ }^{57}$

While the foreign and military policy of Demetrius II (see below) has at least some coverage in the sources, little can be said about his internal policy.

It would not be proper within the scope of this work to discuss the nature of the Macedonian state of the Hellenistic period. ${ }^{58}$ On the basis of the current condition of the sources, we must admit that under the Antigonids the Macedonian state was a complex political and social structure, combining monarchic, city and even federal (or quasi-federal) elements.

${ }^{53}$ E.g. I. Délos 320b, 11. 42-43, 58. See for the details Bruneau 1970, 563-564. Meadows 2013, 37, suggested that the "Demetreia" were established between the late 260 's and 257 B.C. on the occasion of Demetrius II having been named co-regent of Antigonus Gonatas. However, the acceptance of the royal title by Demetrius during his father's lifetime raises much doubt (see above).

${ }^{54}$ See Hammond - Walbank 1988, 318-321.

${ }^{55}$ Polyb. 2.44.1; Plut. Arat. 33.1.

${ }^{56}$ Polyb. 2.44.3.

${ }^{57}$ Cf. Hammond - Walbank 1988, 272-274, 321.

58 The most recent important contribution to the study of the nature of the Macedonian state is still the monograph of M.B. Hatzopoulos "Macedonian Institutions under the Kings" (Hatzopoulos 1996). See also Hatzopoulos 2015, 319-340. 
Practically nothing is known about the court of Demetrius and his "friends" (philoi). One of them was Autocles from Chalcis, " $\varphi$ í $\lambda$ o $\varsigma$

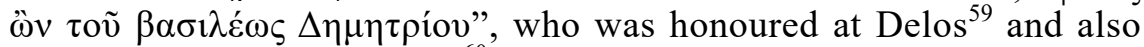
received proxeny in Oropus. ${ }^{60}$

Also at Delos in the 230's B.C. Aristoboulus from Thessalonice was honoured ${ }^{61}$ who was sent to the island as sitones by "king Demetrius"; but we do not know whether Aristoboulus was one of the philoi of the king or not.

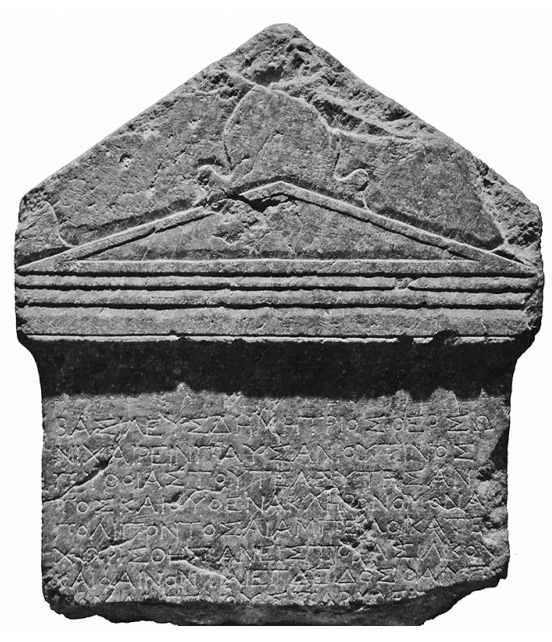

Fig. 3: Letter of Demetrius II to Therson (The Diachronic Museum of Larissa, photograph by Yu. Kuzmin, 2019)

It is evident that an important role in the court of Demetrios II must have been played by the king's cousin, Antigonus, son of Demetrius the Fair. After the death of Demetrius II, Antigonus would become the guardian and the adoptive father of his son Philip, and in due course would become king Antigonus III (229$221 \mathrm{BC}$ ).

Plutarch has a reference to a feast where Demetrius II and his little son Philip were present. ${ }^{62}$ Where the feast was celebrated is not known; the palaces used by the Antigonids have been excavated at Pella, Aegae and Demetrias.

From Stephanus of Byzantium it is known that on the Peneus River Demetrius II founded the city Phila, named in honour of his mother. ${ }^{63}$ The location of the city was the area of Vale of Tempe at the outlet of the Peneus into the Thermaic Gulf. ${ }^{64}$

Recently two important inscriptions from the time of Demetrius II found in Perrhaebia have been published: the letter of the hetairos Philoxenus from the "chiliarchia of Philip" 65 to the king on the occasion of

${ }^{59} I G$ XI.4 680.

${ }^{60}$ On Autocles see Le Bohec 1985, 102.

${ }^{61} I G$ XI.4 666.

${ }^{62}$ Plut. Quaest. Conv. 9.736 f.

${ }^{63}$ Steph. Byz. s.v. Фí $\lambda \alpha$.

${ }^{64}$ Livy 42.67.2; 44.2.12; 44.3.7; 44.7.12; 44.8.1-9; 44.34.10. See also Cohen 1995, 100.

${ }^{65}$ Until recent times, the common opinion was that after the time of Alexander the Great, hetairoi disappeared from political, court and military structures of the Macedonian state. However, since the late 1990's Hellenistic inscriptions from Drama, Nea Potidaea and Perrhaebian Tripolis which mention hetairoi have been published (Hatzopoulos 2001, no. 2.I.b, 11. 25-27; 2.II, 11. 28-29 = SEG XLIX 722, 855; Tziafalias - 
a grant of land, as well as a letter of Demetrius himself on the recovery as state property of the vineyard of a certain Pausanias from Pythium, who died intestate (Fig. 3). ${ }^{66}$ These inscriptions yield valuable additional information about the system of royal grants in Hellenistic Macedonia.

The identification of the coinage of Demetrius II remains problematic. He may have had bronze emissions with the monogram of the name $\Delta \eta \mu \eta \dot{\tau} \tau$ pros in the episema of the "Macedonian" type shield on the obverse (Fig. 4), ${ }^{67}$ but possibly this type was issued by his grandfather Demetrius I. ${ }^{68}$ Demetrius II had no silver emissions in his name. Probably during his reign production continued of the tetradrachms of the types of his father Antigonus Gonatas. ${ }^{69}$
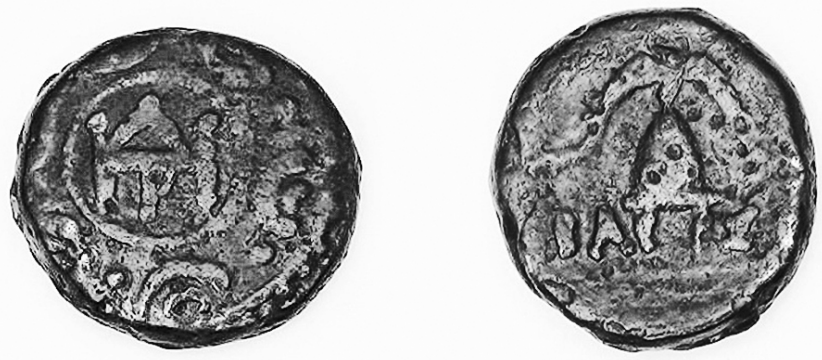

Fig. 4: The bronze coin with the monogram of the name $\Delta \eta \mu \eta \dot{\tau} \tau$ เo (property of the author)

Helly 2010, 72-73, 104-105 = Bull. ép. $2011399=$ SEG LX 586, 604). Hatzopoulos 2001, 34, thinks that in Antigonid Macedonia hetairoi were cavalrymen, as in the time of Alexander. But Sekunda 2013, 50-52, postulated that under the Antigonids hetairos was only a court and honorific title, not a military rank. Nevertheless classical authors (especially Polybius and Livy), as well as the epigraphic sources (the so-called "military regulations" from Amphipolis [Hatzopoulos 2001, no. 3.a.III, 11. 3-4 = $I S E$ 114] and other inscriptions), attest in the court of the Antigonids only "friends" (philoi), but not hetairoi. It is significant that the inscriptions from Drama, Nea Potidaea and Perrhaebia mention hetairoi along with hegemones, i.e. military officers. This definitely indicates that hetairoi were part of a military organization, not a court. It is also very important that the inscriptions of Drama and Nea Potidaea which mention hetairoi deal with the recruitment of the Macedonians and their keeping in reserve. Granted this context, it would be strange if the hetairoi referred to were courtiers. It appears that in the Antigonid army, following the tradition of earlier times, hetairoi were horsemen, probably the privileged, noble part of the cavalry. The "chiliarchia of Philip" was possibly not only a tactical regiment, but also a mobilization unit, in which a thousand horsemen were registered.

66 Tziafalias - Helly 2010, 72-73, 85 = Bull. ép. 2011399 = SEG LX 604-605. Unfortunately, this royal letter of Demetrius II is not useful for the study of the problem of his regnal years and co-regency with Gonatas (see above) since the lower part of the stele, where probably the date of the document was given, is missing.

${ }^{67}$ E.g. Mørkholm 1991, 135.

${ }^{68}$ Newell 1927, 119-120; cf. Mathisen 1979, 2.

${ }^{69}$ Kremydi 2011, 172-173. 


\subsection{Demetrius II, Phthia and Chryseis}

In the very beginning of the 230's B.C. there took place an approach between Macedonia and Epirus, where after the death of Alexander II his widow Olympias ruled de facto. Epirus was interested in an alliance with Macedonia since after the death of Alexander the Aetolian League started advancing on the Aeacid dynasty's possessions in Acarnania, which had been previously divided between Alexander II and the Aetolians. ${ }^{70}$ The possible alliance between Macedonia and Epirus was sealed by a dynastic marriage: Demetrius II married Phthia, the daughter of Alexander II and Olympias. ${ }^{71}$

The marriage of Demetrius and Phthia cannot be dated prior to 246 B.C., contrary to the belief of some scholars. ${ }^{72}$ Justin mentions that in connection with the marriage of Demetrius and Phthia the former wife of the Antigonid king left Macedonia and went to her "brother Antiochus". ${ }^{73}$ Following the traditional viewpoint, the predecessor of Phthia - and that could only have been Stratonice (see above) - went to Antiochus II, who died in 246 B.C. (hence the dating of the marriage of Demetrius and Phthia before then). However, Stratonice was probably the daughter of Antiochus II, and her "brother" is to be seen, most likely, in Seleucus II or his brother and rival Antiochus Hierax. ${ }^{74}$

According to Justin, Demetrius married Phthia only after her father Alexander II's death. The time of his death has been the subject of long debate. But recently among the documents on asylia of the Asclepius temple at Cos there has appeared a decree of Leucas, ${ }^{75}$ which was part of Alexander II's kingdom; the decree is dated by the reign of Alexander (unfortunately the year has been lost owing to the damage of the stone). We know, however, that the theoroi from Cos visited the Balkans in the summer of 243 or 242 B.C. ${ }^{76}$ Thus Alexander II was still alive in the late 240 's B.C., and there is no reason to date the marriage

${ }^{70}$ See for the details Dany 1999, 87-97.

${ }^{71}$ Just. 28.1.1-3.

72 E.g. Cabanes 1976, 60-64; Ogden 1999, 179; Lane Fox 2011, 516, 518.

73 Just. 28.1.2-4; cf. Jos. Ap. 1.206-207.

${ }^{74} \mathrm{On}$ the return of Stratonice to the Seleucid kingdom as well as the problems of interpretation of the information about her uprising against Seleucus II and death (Jos. Ap. 1.206-207), see Gabelko - Kuzmin 2019, 222-224. The mentioned only by Justin (28.1.3-4) war between the Antigonids and Seleucids, supposedly caused by the divorce of Demetrius II and Stratonice, obviously is just invention or mistake of Justin himself.

${ }^{75}$ IG XII.4.1 220.v, 11. 64-71.

76 The time of the visit of the Coan theoroi to Macedonia is known from the decree of Amphipolis dated to the year 41 of the reign of Antigonus Gonatas (IG XII.4.1 220.ii, 1. 19). Gonatas started to style himself basileus after the death of his father Demetrius I (283 or 282 BC.), not after his establishment in Macedonia (c. 277-276 B.C.). On dating the start of the regnal years of Gonatas with the years $284 / 3$ or 283/2 B.C., see Chambers 1954, 385-394; Hammond - Walbank 1988, 581583; Gounaropoulou - Hatzopoulos 1998, 93-94. See also Wheatley 1997, 19-27. 
of his daughter and Demetrius II earlier. ${ }^{77}$ Therefore Phthia became the wife of Demetrius II at the very beginning of his reign, in 239 B.C., and in the next year she gave birth to the heir of the king, the future Philip $\mathrm{V}^{78}$

We must also turn to the question of another probable marriage of Demetrius II. It is known from Eusebius that Demetrius "married one of the captives and named her Chryseis", and that she gave birth to Philip. ${ }^{79}$ Several sources affirm that the successor of Demetrius, Antigonus III Doson, adopted his son Philip and married Demetrius's widow, who however was not mentioned by name; ${ }^{80}$ and it follows from Polybius that at least c. 227 B.C. the spouse of Doson was none other than Chryseis. ${ }^{81}$ The question who was the mother of Demetrius's son, king Philip V - Phthia or Chryseis - is one of the most difficult problems of the dynastic history of the Antigonids.

In the middle of the 230's B.C., i.e. after the birth of Philip, it is Phthia who is mentioned in Athenian inscriptions as the spouse of Demetrius II. ${ }^{82}$ Nevertheless, many researchers think that Philip was born to Chryseis, who could have been a concubine of Demetrius during his marriage to Phthia. This view is justified in most detail by C.F. Edson, ${ }^{83}$ who later, however, clearly accepted the elegant hypothesis of Tarn that Chryseis is just a nickname of Phthia. ${ }^{84}$

It is most probable that the mother of Philip was none other than the Epirote princess Phthia, whether it was she who had borne the nickname Chryseis or Chryseis was some other woman. ${ }^{85}$

It must be noted that examples are known when Philip V, already a king, referred to Antigonus III as "father", ${ }^{86}$ although the majority of

${ }^{77}$ Cf. Hatzopoulos 2007, 273.

${ }^{78}$ On the dating see Walbank 1940, 9, 295-299.

${ }^{79}$ Euseb. Chron. I.238 Schoene; cf. Sync. 282a, p. 535 Dindorf; Etym. Magn. 294 s.v. $\Delta \omega \dot{\sigma \omega v}$.

${ }^{80}$ Plut. Aem. 8.3; Paus. 7.7.4; Just. 28.3.10.

${ }^{81}$ Polyb. 5.89.6-7.

${ }^{82} I G$ II $^{2} 1299,11.10-11$; cf. II ${ }^{3} 1029,11.16-17$.

${ }^{83}$ Dow - Edson 1937, 127-180; cf. Errington 1990, 288, n. 44; Ogden 1999, 179182; Carney 2000, 190-192, 230; Lane Fox 2011, 516, 518.

${ }^{84}$ Tarn 1940, 483-501 (Walbank 1940, 9-10, n. 3, reports that in a personal letter Edson informed him that he accepted the identification of Phthia with Chryseis proposed by Tarn).

${ }^{85}$ See Le Bohec 1981, 34-46. This article contains a basic historiography and good arguments for Phthia as mother of Philip V, to which can be added the following. Phthia's grandfather, the king Pyrrhus, as well as the Bithynian prince Prusias "Monodous", the son of Prusias II, possessed a rare dental defect: gemination, or the merging of teeth (Plut. Pyrrh. 3.6; Livy Per. 50; Val. Max. 1.8.12; Plin. N.H. 7.6970). This hereditary genetic malformation had probably found its way to the Bithynian royal house via the Antigonids after Prusias I's marriage to Philip V's supposed sister Apama (Polyb. 15.22.1; Strabo 12.4.3/564), who should be identified as the daughter of Phthia, not Stratonice, the first wife of Demetrius (see for the details Gabelko - Kuzmin 2008, 159-162). 
sources, both inscriptions and classical authors, term him "son of Demetrius". ${ }^{87}$ It is possible that Chryseis, who might even not have been connected to Demetrius II in any way, but was the wife of Antigonus Doson, was mistakenly recognised by the later authors as the "mother" of Philip V, who was adopted by Doson.

\subsection{The Demetrian War}

The central event in the history of Macedonia and Greece in the 30 's of the third century B.C. was the so-called "Demetrian War" (c. $238-229$ B.C.) ${ }^{88}$ named after Demetrius II (and that was a view not from the Macedonian side). In this war the kingdom of the Antigonids and its allies fought the Aetolian-Achaean alliance. ${ }^{89}$ It is not known which coalition was established first: between the Achaean and Aetolian Leagues against Macedonia or alliance between Macedonia and Epirus. The Demetrian War began in the year of the Athenian archon Lysias $(239 / 8$ or $238 / 7$ B.C. $),{ }^{90}$ as the inscription which glorifies the general Aristophanes, who headed the garrisons in Eleusis, Panactum and Phyle, informs us. ${ }^{91}$

It is possible that on the eve of or during the Demetrian War Ptolemy III became the ally of the Aetolians. ${ }^{92}$ The group with statues of his family was erected on behalf of the Aetolian League in Thermum, ${ }^{93}$ the religious and political centre of Aetolia, probably in the early 230 's B.C. ${ }^{94}$ The Achaean League was already an ally of the Ptolemies from an earlier time. ${ }^{95}$ The support from Ptolemy III for the Achaeans and Aetolians was financial, not military. ${ }^{96}$

At first sight, the Demetrian War may be considered for the Greeks as a war of liberation. However, the actual situation is much more complex, since the slogan of liberation of the Greek states depending on Macedonia was the pretext for the Achaeans and Aetolians to try to expand their Leagues, in which they had become quite successful by

${ }^{86}$ In the royal letters of Philip V from Labraunda in Caria (see Le Bohec 1993, 329-331). Probably it is Antigonus III who is mentioned as "father" in the letter of Philip V from Amphipolis (SEG XXVII 245; XXXIII 499). Cf. Polyb. 4.24.7; 4.87.6.

${ }^{87}$ E.g. EKM I 17; II.2 400, 442; IG IV 427; IV ${ }^{2}$ 590, 11. 1-2; X.2.1 25; Polyb. $1.3 .1 ; 2.2 .5 ; 4.2 .5$; Paus. 1.36.5-6.

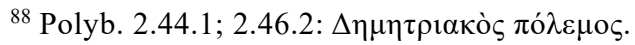

${ }^{89}$ On the Demetrian War see e.g. Costanzi 1910, 59-79; Ehrhardt 1975, I, 208222; Urban 1979, 63-96; Marasco 1980, 113-122; Hammond - Walbank 1988, 324336; Habicht 1997, 163-166; Grainger 1999, 217-243; Scholten 2000, 131-163.

${ }^{90}$ See Osborne 1989, 219-220, 226.

${ }^{91} I G \mathrm{II}^{2}$ 1299, 11. 56-57.

${ }^{92}$ Cf. Scholten 2000, 137-138.

${ }^{93}$ IG IX.1. ${ }^{2} 156$.

${ }^{94}$ Bennett 2002, 141-145.

${ }^{95}$ Plut. Arat. 24.4.

${ }^{96}$ See Scherberich 2009, 27-31. 
the end of the war. Ptolemy III, supporting the enemies of Macedonia, tried to weaken his main rival in the fight for influence in Greece and Aegean.

One of the goals of Macedonia in that war, apart from the defence of its sphere of influence and allied states against the Achaeans and Aetolians, was to recover Corinth (as follows from Plutarch ${ }^{97}$ ).

Evidently it was in connection with the beginning of the war against the Aetolian-Achaean coalition that Demetrius II entered into an alliance with Gortyn on Crete in 237 B.C. ${ }^{98}$ Crete was famous for its mercenaries, whom, beyond doubt, Demetrius needed greatly. It is possible that Etearchus, son of Pyrrhus, from Crete, who in the 220's B.C. made a dedication in Demetrias in the honour of king Antigonus III and his adopted son Philip, the natural son of Demetrius II, ${ }^{99}$ was engaged in the Demetrian War.

In 217 B.C., in the army of Ptolemy IV there were a few men who, according to Polybius, had previously participated in the military campaigns of Demetrius II and Antigonus III: Echecrates, Phoxidas and Eurylochus from Thessaly, Socrates from Boeotia, and Cnopias from Crete. ${ }^{100}$

Two people whose names did not survive in the inscription were engaged in the campaigns "with king Demetrius"; they are honoured in the fragmentary decree of Thessalonice. ${ }^{101}$

The names of a few generals of Demetrius II are known: Agias, Bithys, Dicaearchus, Diogenes, Philip, ${ }^{102}$ et al.

We can agree with C. Ehrhardt that the Demetrian War consisted of a series "of isolated incidents, raids" and so on in several "frontlines" (the Peloponnese, Attica, middle and north-western Greece). ${ }^{103}$ It is likely that the war did not include any general battle.

Out of the few episodes of the Demetrian War we know of the defeat of the Achaeans led by Aratus by the Macedonian general Bithys near mysterious "Phylacia". ${ }^{104}$ The date and location of this battle remain a point of discussion, but it is most likely to be referred to the strategia of Aratus in the years 237/6, 235/4 or 233/2 B.C. The location could be Attica, which is suggested by Plutarch's narrative; or it

\footnotetext{
${ }^{97}$ Plut. Arat. 34.2-3.

${ }^{98}$ IC IV $167=$ SVA III 498.

${ }^{99}$ SEG XII $308=$ ISE 106.

${ }^{100}$ Polyb. 5.63.11-13; 5.65.2-7.

${ }^{101} I G$ X.2.1 1 .

102 Agias (Plut. Arat. 29.6), Bithys (Plut. Arat. 34.2), Dicaearchus (SEG XXV 155 = ISE 25), Diogenes (Plut. Arat. 34.2-3, 6), Philip (Tziafalias - Helly 2010, $72-$ $73=$ Bull. ép. $2011399=$ SEG LX 604).

${ }^{103}$ Ehrhardt 1975, I, 214.

104 Plut. Arat. 34.2-4.
} 
could be the Peloponnese, where in Arcadia there had been a place called Phylace. ${ }^{105}$

Attica, under the attacks of the Achaeans, was one of the main battle-grounds during the Demetrian War. It is also known that the shores of Attica were raided by Aetolian pirates. ${ }^{106}$ The information about the situation in the north-east of Attica about the mid 230's B.C. (in the archonship of Ecphantes) is derived from the decree from Rhamnous to honour Dicaearchus, the Antigonid general in Eretria on Euboea, who had been defending the opposite coast of Attica as well. ${ }^{107}$

C. 236-235 B.C. the Macedonian troops led by Demetrius II invaded Boeotia, which, following its defeat by the Aetolians in the battle of Chaeronea in 245 B.C., had been a forced to become an ally of the Aetolian League. After the Macedonian invasion the Boeotians took the side of the Antigonids. ${ }^{108}$

In 1942 M. Feyel made a proposal that during the Demetrian War the Macedonians succeeded not only in taking Boeotia, but Megaris as well, which had been within the Achaean League since $243 / 2$ B.C. The hypothesis of Feyel was based on a new interpretation of

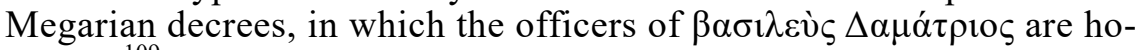
noured. ${ }^{109}$ In Feyel's opinion, this king was not Poliorcetes, as had been thought before, but Demetrius II. ${ }^{110}$ The proposals of Feyel were accepted by some historians, ${ }^{111}$ but became the object of criticism from others. ${ }^{12}$

Recently, however, serious arguments (based on the letter forms of the inscriptions, historical considerations, and prosopography) supporting Feyel's hypothesis about the conquest of Megaris by Demetrius II have been presented by P. Paschidis and A. Robu. ${ }^{113}$ But almost the same arguments (especially historical considerations and prosopographical observations) were used by Ch. Chrysafis in support of theo-

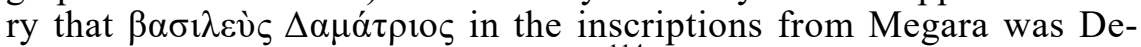
metrius Poliorcetes, not his grandson. ${ }^{114}$

${ }^{105}$ See Porter 1937, 70-71. Bithys, son of Cleon, from Lysimachia, who received Athenian citizenship ( $\left.I G \mathrm{II}^{3} 924\right)$, was probably a courtier of king Lysimachus (Ath. 6.246e; 14.614f; SEG XXXVIII 619, 1. 10; cf. EKM II.2 451), not the general of Demetrius II (see Burstein 1979, 39-50; Hatzopoulos 1988, 38-39).

${ }^{106} I G \mathrm{II}^{2} 844,11.4-7$.

107 SEG XXV $155=$ ISE 25.

${ }^{108}$ Polyb. 20.3.5. On the date see Hammond - Walbank 1988, 326-329.

109 E.g. IG VII 1, 5-6.

${ }^{110}$ Feyel 1942, 85-100.

${ }^{111}$ E.g. Ehrhardt 1975, I, 215; Will 1979, 346, 348.

112 E.g. Etienne - Knoepfler 1976, 323-331; Urban 1979, 66-79; Hammond Walbank 1988, 329.

113 Paschidis 2008, 295-299; Robu 2012, 85-115; Robu 2014, 97-100.

114 Chrysafis 2018, 181-202. 
There were also proposals that Demetrius II was "Demetrius

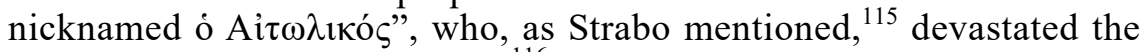
territory of Pleuron in Aetolia. ${ }^{116}$ However, others tend to see in Demetrius "Aetolicus" Demetrius Poliorcetes, who was at war with the Aetolians in 289 B.C. ${ }^{117}$ and also ravaged their country, ${ }^{118}$ and E. Kirsten suggested that "Aetolicus" could be even the Illyrian dynast Demetrius of Pharus. ${ }^{119}$

It should be noted that from Strabo's account it does not follow at all that it was an attack on the territory of Pleuron which led to the fact that a certain Demetrius was called "Aetolicus". This nickname should rather indicate that its owner fought for a long time against the Aetolians, for the appearance of the nickname "Aetolicus" was hardly a result of that one campaign. In this connection Demetrius II seems to be a more suitable candidate for the nickname "Aetolicus" than Demetrius Poliorcetes or Demetrius of Pharus.

It is likely enough that the devastation of the territory of Pleuron did take place during the Demetrian War. ${ }^{120}$ The relocation of the settlement by the citizens of Pleuron from the coast, as mentioned by Strabo, is an indication that the city suffered an attack or menace from the sea (and Boeotia or Megaris could have been used as bases by Demetrius $\left.\mathrm{II}^{121}\right)$.

One way or another, even the probable Macedonian raid on the Aetolian coast did not radically change the situation in the Demetrian War in favour of the Antigonid kingdom. The nickname "Aetolicus", was probably ironic, since Demetrius II never attained a great success in the war against the Aetolians. ${ }^{122}$

The Achaeans, on the contrary, did have a major success in making Megalopolis and Orchomenus join their League. But, at the same time, Aratus did not manage to "liberate" Argos, where after the death of the tyrant Aristippus in the battle against the Achaeans, his brother Aristomachus established his rule with the assistance of the Macedonian troops. ${ }^{123}$ Athens was yet another unattainable goal for Aratus, since the Athenians kept their loyalty to Macedonia until the death of Demetrius II.

115 Strabo $10.2 .4 / 451$.

116 E.g. Woodhouse 1897, 124, 127, n. 3; 135; Ehrhardt 1978, 251-253; Hammond - Walbank 1988, 323-324; Grainger 1999, 225-226; Scholten 2000, 137, 145-146. See also Baldwin 1988, 116-117; Lippman 2004, 497-512.

117 Plut. Demetr. 41.1-2; id. Pyrrh. 7.4.

118 Beloch 1927, 136-137, 528.

119 Kirsten 1951, 243.

120 Pleuron was the native city of Pantaleon, the Aetolian statesman who together with Aratus of Sicyon was a creator of the Aetolian-Achaean anti-Macedonian alliance. If "Aetolicus" was indeed Demetrius II, Pleuron could be his target because it was the native city of Pantaleon (cf. Scholten 2000, 137).

${ }^{121}$ Cf. Ehrhardt 1975, I, 220.

122 Cf. Lane Fox 2011, 517.

${ }^{123}$ Plut. Arat. 29.6. 
Some time in the second half of the 230's B.C. the main focus of attention of Demetrius II was on the north-western frontier of the Macedonian kingdom, where attacks of the Illyrian tribe of the Dardanians became more frequent. ${ }^{124}$ From Livy it is known that the king of the Dardanians, with whom Demetrius II was at war, was a certain Longarus. ${ }^{125}$

At the same time the Aeacid dynasty fell in Epirus (c. 233-232 B.C.), which resulted from internal troubles as well as military pressure from the Aetolians. Following that, a federal state was established in Epirus with an unstable foreign policy. In their turn, the Acarnanians from the former Epirote kingdom partly restored their League and continued the fight against the Aetolians. ${ }^{126}$

In 231 B.C., the citizens of the Acarnanian city Medeon asked for help from Demetrius II, since their city was besieged by the Aetolians. The Macedonian king, who obviously had been engaged in the war against the Dardanians and had had no possibility of providing personal assistance to the Acarnanians, bribed Agron, the king of the Illyrian tribe of the Ardiaei. Complying with the agreement, Agron sent troops to Medeon and they defeated the Aetolians. ${ }^{127}$

It is tempting to connect with the campaign of Demetrius II against the Dardanians the fragments of three shields of the "Macedonian" type ${ }^{128}$ with the inscriptions " $\beta \alpha \sigma \imath \lambda \varepsilon \dot{\varepsilon} \omega \varsigma \Delta \eta \mu \eta \tau \rho$ íov" around the episema, which were discovered at Staro Bonče (north of ancient Macedonia, region of Pelagonia). Yet the archaeological context shows that their date belongs rather to the time of Demetrius Poliorcetes, since the site of their discovery was probably abandoned after the Celtic invasion in 279 B.C. ${ }^{129}$

One more shield bearing the name of " $\beta \alpha \sigma \imath \lambda \varepsilon[\omega \varsigma \Delta \eta \mu \eta \tau \rho]$ íov" was discovered in Dium (Fig. 5). It is also probably to be referred to Demetrius I (among the reasons there is the letter style of the inscription). ${ }^{130}$

However, it is not wise to exclude the person of Demetrius II as the king whose name appears on the shields from Staro Bonče and Dium. ${ }^{131}$ The inscriptions on the shields do not indicate their owner but

124 Trog. Prol. 28.

${ }^{125}$ Livy 31.28.2.

126 See for the details Cabanes 1976, 97-100; Dany 1997, 98-135.

127 Polyb. 2.2-3.

128 The shields of the "Macedonian" type, a part of the protective armour of the Macedonian infantry in the Hellenistic age, had such important features as dimensions, decoration (with geometric and astral motifs) and symbolic meaning (see Liampi 1998, 1-8).

${ }^{129}$ Bitrakova Grozdanova 2007, 863-871; Juhel - Temelkoski 2007, 165-180; Juhel - Temelkoski 2011, 177-191.

${ }^{130}$ Pandermalis 2000, XVIII-XXII. Cf. SEG XLIX 702.

${ }^{131}$ Recently, a "Macedonian" type shield, of unknown provenance, with the same inscription "of the king Demetrius" was bought by the Metropolitan Museum of Art. 
only production at the cost of the king; that was a common practice in the Hellenistic monarchies. ${ }^{132}$

The end of the reign of Demetrius II was marked by defeat of the Macedonian army by the Dardanians. ${ }^{133}$ The exact date, location and the circumstances of the battle are unknown. It must have happened in 230-229 B.C. somewhere in the north-western borders of the Macedonian kingdom.

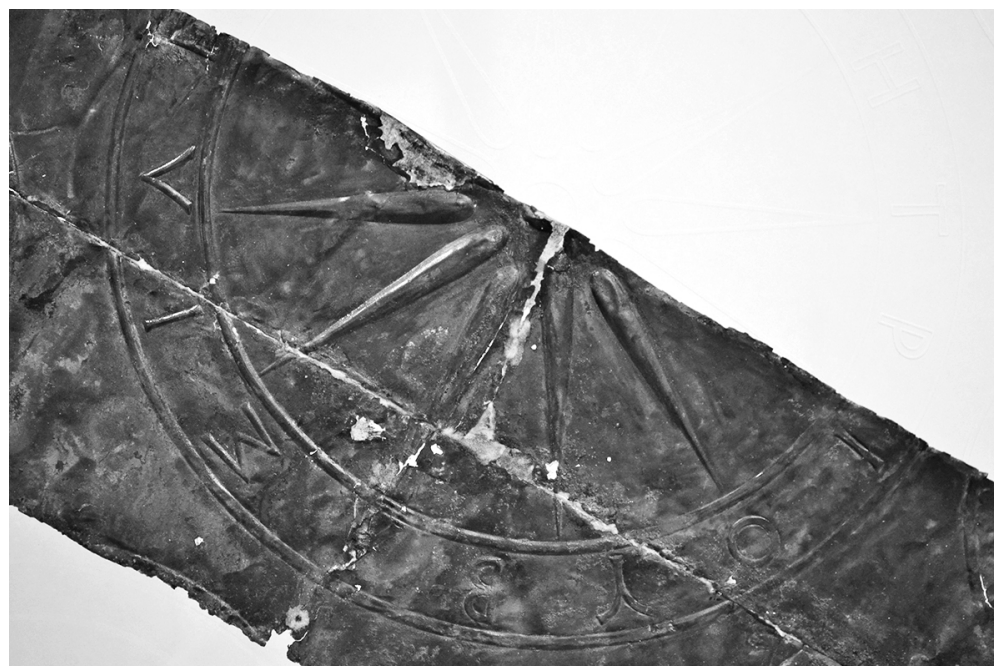

Fig. 5: The central part of the "Macedonian" type shield with the name of " $\beta \alpha \sigma i \lambda \varepsilon \varepsilon[\omega \varsigma$ $\Delta \eta \mu \eta \tau \rho]$ iov" (The Archaeological Museum of Dium, photograph by Yu. Kuzmin, 2016)

In the spring of 229 B.C., probably soon after his defeat by the Dardanians, Demetrius II died at the age of c. 45 and left throne to his son, the 9-year-old Philip V. ${ }^{134}$ We cannot affirm that Demetrius fell in a battle ${ }^{135}$ there are no indications of that in the sources. ${ }^{136}$

Closing the chapter of the Demetrian War, which had been lost by Macedonia at the time of the death of Demetrius II, and defending the kingdom from the Dardanians was now the task of Antigonus III in 229-228 B.C.

It is not known where Demetrius II was buried; as it is not known where the necropolis of the Antigonid dynasty was located. In the region of Pella, the main residence of the Antigonids, several monumental

${ }^{132}$ Cf. Hatzopoulos 2001, 42; Juhel - Temelkoski 2007, 170-171; Juhel 2017, 46-50.

133 Trog. Prol. 28.

${ }^{134}$ According to Polybius (2.44.2), Demetrius II died at the time of the first crossing of the Romans to Illyria. On the date of the king's death see Holleaux 1921, 101, n. 7; Walbank 1957, 238; Le Bohec 1993, 99-101.

${ }^{135}$ E.g. Droysen 1955, 331; Green 1990, 254.

136 Just. 28.3.9; Trog. Prol. 28. Cf. Ehrhardt 1975, I, 226; Hammond - Walbank 1988, 336, n. 1; Le Bohec 1993, 98-99. 
"Macedonian" tombs have been discovered, ${ }^{137}$ but there are no reasons to consider them to be exclusively royal. On the other hand, it is possible that the tombs of the Antigonids were situated in Beroea, which was probably their native city, ${ }^{138}$ or even in Aegae.

\section{Epilogue}

The death of Demetrius II led to an almost complete disorganization of the system of Macedonian influence and military presence in Greece. During 229 B.C. the last tyrant regimes in the Peloponnese had fallen (in Argos, Hermione and Phlius) and Attica was liberated from the Antigonid garrisons. The same time is marked by the shortterm breaking away of Thessaly from the kingdom of the Antigonids with the support of the Aetolians.

Also the situation in Macedonia was not stable, and this induced the leading Macedonian nobles to invoke as "regent and general" 139 the late king's cousin Antigonus. Soon he accepted the royal title while officially admitting Philip V to be his heir. By the end of the 220's B.C. Antigonus III succeeded in recovering and strengthening the positions of Macedonia in Greece and the Aegean.

In 221 B.C., following the death of Antigonus III, Philip V, the son of Demetrius II, ascended to the Macedonian throne. During the first half of Philip's reign (until the turn of the third and second centuries B.C.) Macedonia was an empire encompassing the territories from the Adriatic to Caria. This was ended when confrontation with Rome ensued and grew; this conflict became fatal for the Macedonian kingdom. The grandson of Demetrius II, Perseus (179-168 B.C.), was the last of the kings from the Antigonid dynasty.

Concerning the internal policy of Demetrius II, the recently published inscriptions from Perrhaebia show that knowledge about it may yet be expanded thanks to the discovery of the new epigraphic sources. In assessing the foreign policy of Demetrius II, we must remember the complicated inheritance he had from his father. The diplomatic and military activities of Demetrius with their ups and downs were his answer to those challenges. ${ }^{140}$

${ }^{137}$ Chrysostomou 2003, 81-91, 144-146.

138 On Beroea as the native city of the Antigonids, see Edson 1934, 213-246; Kuzmin 2013b, 28-31.

139 Plut. Aem. 8.3.

${ }^{140}$ I should like to extend my thanks to P. J. Rhodes as well as to O. L. Gabelko, K. M. Kalinin, I. A. Ladynin, S. Lehmann, Chr. Mileta, V. P. Nikonorov and V. Sarakinski. None of them, of course, is responsible for the conclusions set forth in this paper. 


\section{BIBLIOGRAPHY}

Adams, W. L. 2010: “Alexander's Successors to 221 B. C. ”, in: J. Roisman - I. Worthington (edd.), A Companion to Ancient Macedonia, Malden, MA, 208-224.

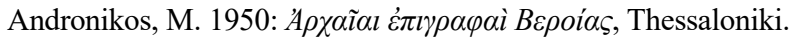

Badian, E. 1997: "Demetrios (3)", in: Der neue Pauly III, Stuttgart, 429.

Baldwin, B. 1988: "Demetrius 'Aetolicus'”, Hermes 116. 1, 116-117.

Beloch, K. J. 1927: Griechische Geschichte ${ }^{2}$ IV. 2, Berlin-Leipzig.

Bennett, C. 2002: "The Children of Ptolemy III and the Date of the Exedra of Thermos", Zeitschrift für Papyrologie und Epigraphik 138, 141-145.

Bitrakova Grozdanova, V. 2007: "Macedonian Shield from Bonče“, in: M. Blečić et al. (edd.), Scripta Praehistorica in honorem Biba Teržan, Ljubljana, 863-871.

Le Bohec, S. 1981: "Phthia, mère de Philippe V: examen critique des sources", Revue des études grecques 94, 34-46.

— 1985: "Les philoi des rois Antigonides", Revue des études grecques 98, 93-124.

- 1993: Antigone Dôsôn, roi de Macédoine, Nancy.

— 2005: "L'héritier du diadème chez les Antigonides", in: V. Alonso Troncoso (ed.), $\Delta ı \alpha ́ \delta o-$ $\chi о \varsigma \tau \tilde{\eta} \varsigma \beta \alpha \sigma i \lambda \varepsilon i \alpha \varsigma$. La figura del sucesor en la realeza helenistica, Madrid, 57-70.

Bruneau, Ph. 1970: Recherches sur les cultes de Délos à l'époque hellénistique et à l'époque impériale, Paris.

Buraselis, K. 2005: "Kronprinzentum und Realpolitik. Bemerkungen zur Thronanwartschaft, Mitregentschaft und Thronfolge unter den ersten vier Ptolemäern", in: V. Alonso

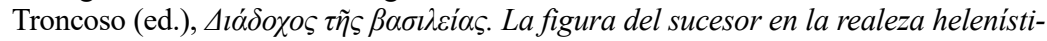
ca, Madrid, 91-102.

Burstein, S. M. 1979: "Bithys, Son of Cleon from Lysimachia: A Reconsideration of the Date and Significance of IG II ${ }^{2}, 808$ ", California Studies in Class. Antiquity 12, 39-50.

Cabanes, P. 1976: L'Épire de la mort de Pyrrhos à la conquête romaine (272-167 av. J. -C.), Paris.

Carney, E. D. 2000: Women and Monarchy in Macedonia, Norman, OK.

Chambers, M. 1954: "The First Regnal Year of Antigonus Gonatas", American Journal of Philology 75. 4, 385-394.

Chrysafis, Ch. I. 2018: "A Note on the History of Hellenistic Megara: The Date of the Antigonid Garrison in Aegosthena", Tekmeria 14, 181-202.

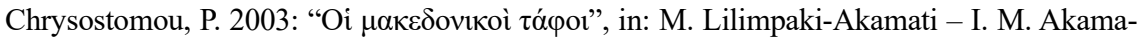

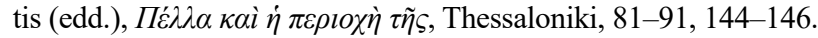

Cohen, G. M. 1995: The Hellenistic Settlements in Europe, the Islands, and Asia Minor, Berkeley-Los Angeles.

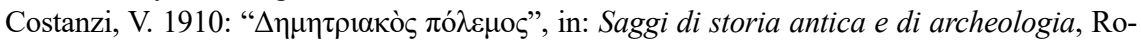
me, 59-79.

Dany, O. 1999: Akarnanien im Hellenismus. Geschichte und Völkerrecht in Nordwestgriechenland, Munich.

Dixon, M. D. 2014: Late Classical and Early Hellenistic Corinth, 338-196 B.C., LondonNew York.

Dow, S. - Edson, C. F. 1937: "Chryseis: A Study of the Evidence in Regard to the Mother of Philip V”, Harvard Studies in Classical Philology 48, 127-180.

Droysen, J. G. 1955: Geschichte des Hellenismus III. Geschichte der Epigonen, Tübingen.

Edson, C. F. 1934: "The Antigonids, Heracles and Beroea", Harvard Studies in Classical Philology 45, 213-246.

Ehrhardt, C. T. H. R. 1975: Studies in the Reigns of Demetrius II and Antigonus Doson I-II, Diss. SUNY, Buffalo. 
— 1978: "Demetrius ó Ai $\tau \omega \lambda$ ıкó $̧$ and the Antigonid Nicknames", Hermes 106. 1, 251-253.

Errington, R. M. 1977: “An Inscription from Beroea and the Alleged Co-rule of Demetrius II", in: Ancient Macedonia-II, Thessaloniki, 115-122.

— 1990: A History of Macedonia, Berkeley-Los Angeles-London.

Etienne, R. - Knoepfler, D. 1976: Hyettos de Béotie et la chronologie des archontes fédéraux entre 250 et 171 avant $J$. -C., Paris.

Feyel, M. 1942: Polybe et l'histoire de Béotie au III-e siècle avant notre ère, Paris.

Gabbert, J. J. 1997: Antigonus II Gonatas: A Political Biography, London-New York.

Gabelko, O. L. - Kuzmin, Yu. N. 2008: “Матримониальная политика Деметрия II Македонского: новые решения старых проблем (The Matrimonial Policy of Demetrius II of Macedon: The New Solutions for Old Problems)", Вестник древней истории (Journal of Ancient History) 1(264), 141-164.

- 2019 (forthcoming): "A Case of Stratonices: Two Royal Women between Three Hellenistic Dynasties", in: R. Oetjen (ed.), New Perspectives in Seleucid History, Archaeology and Numismatics. Studies in Honor of Getzel M. Cohen, Berlin, 202-225.

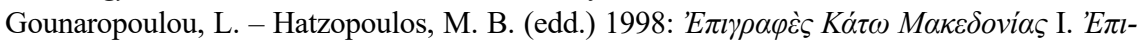

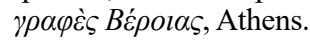

Grainger, J. D. 1999: The League of the Aitolians, Leiden.

Green, P. 1990: Alexander to Actium. The Historical Evolution of the Hellenistic Age, Berkeley-Los Angeles.

Grzybek, E. 1993: “Eine Inschrift aus Beroia und die Jahreszählweisen der Diadochen”, in: Ancient Macedonia-V, Thessaloniki, 521-527.

Habicht, Chr. 1997: Athens from Alexander to Antony, Cambridge, MA.

Hammond, N. G. L. 1989: The Macedonian State. Origins, Institutions, and History, Oxford.

Hammond, N. G. L. - Walbank, F. W. 1988: A History of Macedonia III. 336-167 B.C., Oxford.

Hatzopoulos, M. B. 1988: Une donation du roi Lysimaque, Athens.

— 1990: "Un nouveau document du règne d'Antigone Gonatas", in: M. B. Sakellariou (ed.), Поккі $\lambda$, Athens, 135-155.

- 1996: Macedonian Institutions under the Kings I. A Historical and Epigraphic Study, Athens.

— 2001: L'organisation de l'armée macédonienne sous les Antigonides: problèmes anciens et documents nouveaux, Athens.

— 2007: "Décrets d'asylie, de Macédoine et d'Epire" in: D. Berranger-Auserve (ed.), Épire, Illyrie, Macédoine... Mélanges offerts au Professeur Pierre Cabanes, Clermont-Ferrand, 271-274.

- 2015: "Federative Makedonia" in: H. Beck - P. Funke (edd.), Federalism in Greek Antiquity, Cambridge, 319-340.

Hazzard, R. A. 1987: “The Regnal Years of Ptolemy II Philadelphos", Phoenix 41. 1, 140158.

Heinen, H. 1972: Untersuchungen zur hellenistischen Geschichte des 3. Jahrhunderts v. Chr. Zur Geschichte der Zeit des Ptolemaios Keraunos und zum Chremonideischen Krieg, Stuttgart.

Holleaux, M. 1921: Rome, la Grèce et les monarchies hellénistiques au III-e siècle avant J.C.(273-205), Paris.

Juhel, P. O. 2017: Armes, armement et contexte funéraire dans la Macédoine hellénistique. Avec un appendice sur les trouvailles d'armes relatives à l'archaïsme et aux débuts de l'époque classique en Macédoine \& sur ses confins, Gdańsk.

Juhel, P. - Temelkoski, D. 2007: “Fragments de 'boucliers macédoniens' au nom du roi Démétrios trouvés à Staro Bonče (République de Macédoine). Rapport préliminaire et présentation épigraphique", Zeitschrift für Papyrologie und Epigraphik 162, 165180. 
- 2011: “Découverte de nouveaux 'boucliers macédoniens' en Pélagonie (République de Macédoine). Aspects archéologiques et réflexions historiques", in: J.-C. Couvenhes - S. Crouzet - S. Péré-Noguès (edd.), Pratiques et identités culturelles des armées hellénistiques du monde méditerranéen. Hellenistic Warfare 3, Bordeaux, 177-191.

Kaerst, J. 1901a: "Demetrios (34)", in: Paulys Real-Encyclopädie der classischen Altertumwissenchaft. Neue bearbeitung IV, Stuttgart, 2792-2793.

- 1901b: "Demetrios (35)", in: Paulys Real-Encyclopädie der classischen Altertumwissenschaft. Neue bearbeitung IV, Stuttgart, 2793.

King, C. 2018: Ancient Macedonia, London-New York.

Kirsten, E. 1951: "Pleuron", in: Paulys Real-Encyclopädie der classischen Altertumwissenschaft. Neue bearbeitung XXI, Stuttgart, 239-268.

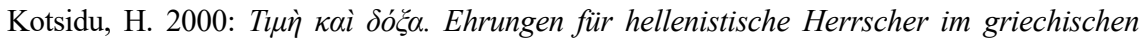
Mutterland und in Kleinasien unter besonderer Berücksichtigung der archäologischen Denkmäler, Berlin.

Kremydi S. 2011: "Coinage and Finance", in: R. Lane Fox (ed.), Brill's Companion to Ancient Macedon: Studies in the Archaeology and History of Macedon, 650 B. C. -300 A.D., Leiden-Boston, 159-178.

Kuzmin, Yu. N. 2013a: "The Macedonian Aristocratic Family of Harpaloi-Polemaioi from Beroea", in: A. Mehl - A. V. Makhlayuk - O. Gabelko (edd.), Ruthenia Classica Aetatis Novae. A Collection of Works by Russian Scholars in Ancient Greek and Roman History, Stuttgart, 123-132.

- 2013b: Аристократия Берои в эпоху эллинизма (The Aristocracy of Beroea in the Hellenistic Epoch), Moscow.

- 2015: "The Antigonids, Caunus and the so-called 'Era of Monophthalmus': Some Observations Prompted by a New Inscription”, in: V. Goušchin - P. J. Rhodes (edd.), Deformations and Crises of Ancient Civil Communities, Stuttgart, 73-85.

Lane Fox, R. 2011: “ 'Glorious Servitude...': The Reigns of Antigonos Gonatas and Demetrius II", in: R. Lane Fox (ed.), Brill's Companion to Ancient Macedon: Studies in the Archaeology and History of Macedon, 650 B.C. - 300 A.D., Leiden-Boston, 495-519.

Liampi, K. 1998: Der makedonische Schild, Bonn.

Lippman, M. B. 2004: "Strabo 10. 2. 4 and the Synoecism of 'Newer' Pleuron", Hesperia 73. 4, 497-512.

Manni, E. 1956: “Antigono Gonata e Demetrio II: punti fermi e problemi aperti”, Athenaeum N. S. 34, 249-272.

Marasco, G. 1980: "La politica achea nel Peloponneso durante la guerra demetriaca", Atene e Roma 25, 113-122.

Mathisen, R. W. 1979: "The Shield/Helmet Bronze Coinage of Macedonia: A Preliminary Analysis", Journal of the Society of Ancient Numismatics 10. 1, 2-6.

Meadows, A. 2013: "The Ptolemaic League of Islanders", in: K. Buraselis - M. Stefanou D. J. Thompson (edd.), The Ptolemies, the Sea and the Nile. Studies in Waterborne Power, Cambridge, 19-38.

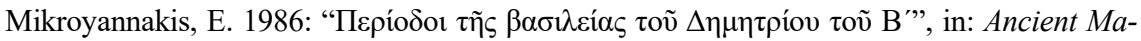
cedonia-IV, Thessaloniki, 393-399.

— 1999: "Chremonidean War and Demetrius II", in: Ancient Macedonia-VI, Thessaloniki, 753-761.

Mørkholm, O. 1991: Early Hellenistic Coinage. From the Accession of Alexander to the Peace of Apamea (336-188 B.C.), Cambridge.

Newell, E. T. 1927: The Coinages of Demetrius Poliorcetes, Oxford.

Niebuhr, B. G. 1828: Kleine historische und philologische Schriften I, Bonn.

- 1852: Lectures on Ancient History, from the Earliest Times to the Taking of Alexandria by Octavianus III, London. 
Ogden, D. 1999: Polygamy, Prostitutes and Death: The Hellenistic Dynasties, LondonSwansea.

Osborne, M. J. 1989: “The Chronology of Athens in the Mid Third Century B. C. ", Zeitschrift für Papyrologie und Epigraphik 78, 209-242.

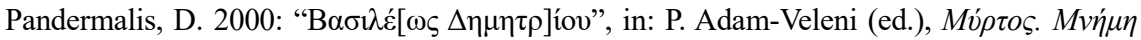

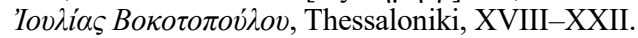

Paschidis, P. 2008: Between City and King. Prosopographical Studies on the Intermediaries between the Cities of the Greek Mainland and the Aegean and the Royal Courts in the Hellenistic Period (322-190 BC), Athens.

Porter, W. H. 1937: Plutarch's Life of Aratus. With Introduction, Notes, and Appendix, Dublin-Cork.

Robu, A. 2012: "La cité de Mégare et les Antigonides: à propos d'une magistrature mégarienne extraordinaire (le collège des six stratèges)", in: Chr. Feyel - J. Fournier - L. Graslin-Thomé - F. Kirbihler (edd.), Communautés locales et pouvoir central dans l'Orient hellénistique et romain, Paris, 85-115.

- 2014: "Between Macedon, Achaea and Boeotia: The Epigraphy of Hellenistic Megara Revisited", in: N. Papazarkadas (ed.), The Epigraphy and History of Boeotia. New Finds, New Prospects, Leiden, 95-118.

Scherberich, K. 2009: "Zur Griechenlandpolitik Ptolemaios III. ”, in: J. -F. Eckholdt - M. Sigismund - S. Sigismund (edd.), Geschehen und Gedächtnis: Die hellenistische Welt und ihre Wirkung. Festschrift für W. Orth zum 65. Geburtstag, Berlin, 25-43.

Scholten, J. B. 2000: The Politics of Plunder. Aitolians and their Koinon in the Early Hellenistic Era, 279-217 B.C., Berkeley-Los Angeles.

Sekunda, N. V. 2013: The Antigonid Army, Gdańsk.

Tarn, W. W. 1913: Antigonos Gonatas, Oxford.

- 1940: "Phthia-Chryseis", in: Athenian Studies Presented to W. S. Ferguson, Cambridge, MA-London, 483-501.

Tataki, A. B. 1988: Ancient Beroea: Prosopography and Society, Athens.

Treves, P. 1932: "La tradizione politica degli Antigonidi e l'opera di Demetrio II", Rendiconti della Reale Accademia nazionale dei Lincei 8, 167-205.

Tziafalias, A. - Helly, B. 2010: "Inscriptions de la Tripolis Perrhébie. Lettres royales de Démétrios II et Antigone Dôsôn”, Studi ellenistici 24, 71-125.

Urban, R. 1979: Wachstum und Krise des Achäischen Bundes, Wiesbaden.

Vasil'evskiy, V. G. 1869: Политическая реформа и соииальное движение в древней Греиии в период ее упадка (The Political Reform and the Social Movement in Ancient Greece in the period of Her Decline), St. Petersburg.

Volkmann, H. 1964: “Demetrios (3)”, in: Der kleine Pauly I, Munich, 1465.

Walbank, F. W. 1940: Philip V of Macedon, Cambridge.

- 1957: A Historical Commentary on Polybius I, Oxford.

- 1984: "Macedonia and the Greek Leagues", in: The Cambridge Ancient History ${ }^{2}$ VII. 1, 446-481.

Wheatley, P. 1997: "The Lifespan of Demetrius Poliorcetes", Historia 46. 1, 19-27.

Will, Éd. 1979: Histoire politique du monde hellénistique (323-30 av. J.-C.) ${ }^{2}$ I, Nancy.

Woodhouse, W. J. 1897: Aetolia. It's Geography, Topography and Antiquities, Oxford.

Zelnick-Abramovitz, R. 2005: Not Wholly Free. The Concept of Manumission and the Status of Manumitted Slaves in the Ancient Greek World, Leiden. 
